\title{
CLINICAL VALIDATION OF THE \\ NANDA-I "CAREGIVER ROLE STRAIN" \\ NURSING DIAGNOSIS IN THE CONTEXT OF PALLIATIVE CARE
}

\author{
Tânia Marlene Gonçalves Lourenço ${ }^{1,2}$ (i) \\ Rita Maria de Sousa Abreu-Figueiredo ${ }^{1,2}$ (1) \\ Luís Octávio Sá ${ }^{3}$ (B)
}

\begin{abstract}
${ }^{1}$ Escola Superior de Enfermagem São José de Cluny, Gabinete de Investigação e Desenvolvimento Cluny. Funchal, Portugal. ${ }^{2}$ Centro de Investigação em Tecnologias e Serviços de Saúde, Grupo de Investigação: Inovação e Desenvolvimento em Enfermagem. Porto, Portugal.
\end{abstract} ${ }^{3}$ Universidade Católica Portuguesa, Centro de Investigação Interdisciplinar em Saúde. Porto, Portugal.

\begin{abstract}
Objective: to clinically validate the defining characteristics of the "Caregiver Role Strain" Nursing diagnosis for caregivers of people in a palliative care situation.

Method: a cross-sectional, quantitative, descriptive and analytical study. It was developed based on Fehring's Clinical Validation Model and on the diagnostic accuracy measures (sensitivity, specificity, predictive values and Receiver Operating Characteristic curve). The data collection instrument used was a form, applied in 2017 by two nurses to a sample of 111 caregivers of people in a palliative care situation, in Portugal. The caregivers were divided into two groups (with and without the diagnosis), being identified by the simultaneity of three criteria, namely: Zarit Burden Interview values greater than 56; agreement of two nurses about the diagnosis; and caregiver's perception of the presence of signs and symptoms. The defining characteristics were classified as major, secondary and irrelevant, according to the models used.

Results: the prevalence of diagnosis was $42.3 \%$. Of the 29 characteristics subjected to the validation process, 9 were considered major, 13 secondary and 7 irrelevant. Ineffective coping, depressive mood, frustration, worsening of previous diseases, stress and fatigue were the characteristics which proved to be more associated with the diagnosis in both analyses. The overall score of the diagnosis was 0.68 .

Conclusion: the study results contribute to the improvement of the diagnosis, making it more accurate. In addition, they enable better clinical decision in Nursing, allowing nurses to make a diagnostic judgment supported by scientific evidence.
\end{abstract}

DESCRIPTORS: Caregivers. Palliative care. Psychological stress. Nursing diagnosis. Validation studies. 


\title{
VALIDAÇÃO CLÍNICA DO DIAGNÓSTICO DE ENFERMAGEM NANDA-I "TENSÃO DO PAPEL DE CUIDADOR" EM CONTEXTO DE CUIDADOS PALIATIVOS
}

\begin{abstract}
RESUMO
Objetivo: validar clinicamente as características definidoras do diagnóstico de enfermagem "Tensão do Papel de Cuidador da pessoa em situação paliativa".

Método: estudo do tipo transversal, de natureza quantitativa, descritivo e analítico. Desenrolou-se ancorado no Modelo de Validação Clínica de Fehring e nas medidas de acurácia diagnóstica (sensibilidade, especificidade, valores preditivos e curva Receiver Operating Characteristic). $\mathrm{O}$ instrumento de coleta de dados utilizado foi um formulário, aplicado por duas enfermeiras, a uma amostra de 111 cuidadores de pessoas em situação paliativa, em Portugal, em 2017. Os cuidadores foram divididos em dois grupos (com e sem diagnóstico), sendo identificados pela simultaneidade de três critérios: valores da escala de sobrecarga do cuidador de Zarit superiores a 56; concordância de duas enfermeiras acerca do diagnóstico; e a percepção do cuidador quanto à presença de sinais e sintomas. Classificaram-se as caraterísticas definidoras em principais, secundárias e irrelevantes, mediante os modelos utilizados.

Resultados: a prevalência do diagnóstico foi de 42,3\%. Das 29 características sujeitas ao processo de validação, 9 foram consideradas principais, 13 secundárias e 7 irrelevantes. O enfrentamento ineficaz, o humor depressivo, a frustração, o agravamento de doenças prévias, o estresse e a fadiga foram as características que se revelaram mais associadas ao diagnóstico em ambas as análises. O score global do diagnóstico foi de 0,68. Conclusão: os resultados do estudo contribuem para o aprimoramento do diagnóstico, tornando-o mais acurado. Ademais, possibilitam melhor decisão clínica em enfermagem, permitindo aos enfermeiros um juízo diagnóstico apoiado em evidências científicas.
\end{abstract}

DESCRITORES: Cuidadores. Cuidados paliativos. Estresse psicológico. Diagnóstico de enfermagem. Estudos de validação.

\section{VALIDACIÓN CLÍNICA DEL DIAGNÓSTICO DE ENFERMERÍA NANDA-I "CANSANCIO DEL ROL DE CUIDADOR" EN EL CONTEXTO DE LOS CUIDADOS PALIATIVOS}

\section{RESUMEN}

Objetivo: validar clínicamente las características definitorias del diagnóstico de Enfermería "Cansancio del rol de Cuidador de personas en situación de cuidados paliativos".

Método: estudio descriptivo y analítico de tipo transversal y naturaleza cuantitativa. Se desarrolló sobre la base del Modelo de Validación Clínica de Fehring y de las medidas de exactitud diagnóstica (sensibilidad, especificidad, valores predictivos y curva Receiver Operating Characteristic). El instrumento para la recolección de dados utilizado fue un formulario, aplicado en el año 2017 por dos enfermeras a una muestra de 111 cuidadores de personas en situación de cuidados paliativos en Portugal. Se dividió a los cuidadores en dos grupos (con y sin el diagnóstico), identificados por la simultaneidad de tres criterios: valores de la escala de Zarit de sobrecarga del cuidador superiores a 56; acuerdo de dos enfermeras acerca del diagnóstico; y percepción del cuidador con respecto a la presencia de señales y síntomas. Las características definitorias se clasificaron como principales, secundarias e irrelevantes, mediante los modelos utilizados.

Resultados: la prevalencia del diagnóstico fue del $42,3 \%$. De las 29 características sujetas al proceso de validación, 9 fueron consideradas como principales, 13 como secundarias y 7 como irrelevantes. Afrontamiento poco eficaz, estado de ánimo depresivo, frustración, deterioro de enfermedades previas, estrés y fatiga fueron las características que demostraron mayor asociación con el diagnóstico en ambos análisis. El score global del diagnóstico fue 0,68 .

Conclusión: los resultados del estudio son útiles para mejorar el diagnóstico, aumentando su exactitud. También hacen posible tomar mejores decisiones clínicas en Enfermería, permitiendo así que los enfermeros tomen determinaciones diagnósticas sobre la base de evidencias científicas.

DESCRIPTORES: Cuidadores. Cuidados paliativos. Estrés psicológico. Diagnóstico de Enfermería. Estudios de validación. 


\section{INTRODUCTION}

The caregiver has been a privileged research target in the health area, and the negative impact on their person deserved special attention from researchers ${ }^{1}$. Aspects related to the caregiver's conditions and to the negative impacts of this practice on their own lives have been the object of several studies nowadays. In these research studies, care recipients are very diverse: older adults ${ }^{2}$, people with dementia ${ }^{3-5}$, physical dependence ${ }^{6}$ or cancer ${ }^{7-8}$ and people in a palliative care situation ${ }^{9-10}$ among others .

Taking care of a family member at the end of life exposes the caregiver to intense experiences in a context of special vulnerability. Caregivers can experiment feelings of ambivalence, being divided between deep involvement in care and high strain/stress.

Nurses are always concerned with the caregiver's well-being, especially in contexts of greater vulnerability, as is the case with palliative care. Taking care of a caregiver who accompanies a family member/significant other at the end of life is challenging, and it is sometimes difficult to diagnose Caregiver Role Strain. In the practice, it is complex to distinguish between the normal tiredness that results from caring for a dependent person and the caregiver's exhaustion. On the other hand, the clinical indicators associated with this phenomenon are very diverse, hindering its diagnosis and the consequent implementation of specific Nursing interventions.

The "Caregiver Role Strain" diagnosis is defined in the NANDA International (NANDA-I) taxonomy as "Difficulty in performing responsibilities, expectations and/or care behaviors for family or significant others"11:544.

Although this phenomenon has been widely studied, its analysis as a Nursing diagnosis is scarce. The NANDA-I taxonomy directs us to the use of duly validated Nursing diagnoses, classified according to the levels of evidence, in consonance with the investigation carried out on each one. The levels of evidence vary upwards from 1.1 to 3.4. The highest level, 3.4, corresponds to diagnoses that were validated by means of randomized clinical trials, whose samples allowed the results to be generalized to the population.

The level of evidence for this diagnosis remains at 2.1, despite being included in the classification for nearly 28 years. Although it has undergone several changes aimed at improving it, it still maintains a high number of defining characteristics and related factors, which can hinder its use. In a previous integrative review, it was found that, although seven validation studies (content/clinical) of the diagnosis had already been carried out, none of them was conducted among caregivers of patients in need of palliative care ${ }^{12}$.

The main objective of this study was to clinically validate the defining characteristics of the Caregiver Role Strain Nursing diagnosis for caregivers of people in a palliative care situation.

\section{METHOD}

This study was predominantly quantitative, cross-sectional, descriptive and analytical. A non-probabilistic convenience sample of 111 caregivers of patients referred to the national network of palliative care in Portugal was used.

The Clinical Diagnostic Validation (CDV) Model for Nursing by Richard Fehring was used, which essentially consists in obtaining evidence through data from the clinical context ${ }^{13-14}$. Diagnostic accuracy, which refers to the potential of a test to discriminate between the studied condition and health, can be quantified through several analysis measures ${ }^{15-16}$. In this study, we used the following measures: sensitivity (Se), specificity (Sp), positive predictive value (PPV), negative predictive value (NPV) and area under the ROC curve (AUC) $)^{17}$.

The data collection instrument was a form, prepared by the researchers, whose construction process included several phases. Initially, an integrative literature review was carried out, with the 
objective of identifying the defining characteristics (DCs) associated with the diagnosis under study. This strategy has been used in several research studies of this nature ${ }^{18-20}$. Subsequently, the characteristics were reformulated and/or grouped to avoid redundancies. In order to elaborate the questions, other instruments used to assess the same construct were consulted. Finally, a panel of 18 judges was consulted regarding the relevance, clarity and precision of each item or question ${ }^{17}$. These judges were selected according to the following criteria: being specialized in the area under study, having more than five years of clinical experience in palliative care or having a $\mathrm{PhD} /$ master's degree in the area.

The data collection instrument consisted of three parts. The first contained sociodemographic and care context data. The second presented the list of defining characteristics, with each participant being asked to inform to what extent each characteristic was indicative of their feelings and/or behaviors, with five answer options: nothing characteristic of me (1); very uncharacteristic of me (2); characteristic in some way (3); quite characteristic (4); and very characteristic (5). Presence of the defining characteristic was considered when a score $\geq 3$ was obtained.

The third part used Zarit's Caregiver Burden Scale ${ }^{21}$, validated for the Portuguese population of family caregivers ${ }^{22}$. This scale is composed of 22 items with five possible answers, whose total score is obtained by the sum of the scores of the items, varying from 22 to 110 . A higher score corresponds to a greater perception of strain, according to the following cutoff points: $<46=$ no burden; between 46 and $56=$ with burden; and $>56=$ intense burden. We obtained a Cronbach's Alpha of 0.811 for the global scale.

To identify the caregivers diagnosed with Caregiver Role Strain, three criteria were established (gold standard): Zarit Burden Interview values greater than 56; agreement of two nurses about the diagnosis (Cohen's Kappa=81.56\%); and the caregiver's perception regarding the presence of signs and symptoms of the diagnosis when asked.

It was decided not to previously select clients with the diagnosis, thus avoiding the influence of prior knowledge and selection bias ${ }^{23}$.

A pre-test was performed with ten caregivers, aiming to validate the instrument and to test the clarity and understanding of the questions, as well as its organization and mean application time.

The inclusion criteria established in this study were as follows: caregivers (consanguineous or affective ties) of patients followed-up by a Portuguese palliative care network, aged 18 years old or over, and who provided care at least twice a week for a minimum period of one month. Caregivers of children with palliative needs were excluded.

The Nursing diagnosis under study translates a cognitive-affective response, which is why it was decided to collect the data directly from the participants, as recommended by the author of the model. The structured interviews were conducted in 2017 by two experienced researchers in the area of the diagnosis under study, in a private and welcoming environment, in the Inpatient Unit facilities $(n=56)$ and in the patients' homes $(n=55)$. It is noted that the patient was never present during the interviews, but was always informed about the study being conducted, as long as the clinical condition allowed so. Each interview lasted a mean of 50 minutes, after which debriefing took place, where the caregiver was asked about the experience of participating in the study. The caregivers who presented obvious signs of extreme burden were referred to the multidisciplinary team of the palliative care unit.

For data treatment, descriptive and inferential statistics were resorted to, using the Statistical Package for Social Sciences, version 20.

The criteria to classify the defining characteristics were based on the articulation between the different methods used: Fehring's model and the diagnostic accuracy measures. The characteristics that obtained scores $\geq 0.8$ were classified as major; and, as secondary, those withscores between 0.5 and 0.7 . The characteristics with scores $<0.5$ in the CDV are considered irrelevant and, in the AUC analysis, they presented values that were not statistically significant. 
This research received a favorable opinion from the Health Ethics Committee of the Autonomous Region of Madeira, a Public Business Entity. It also observed the participants' autonomy and right of refusal, through the free and informed consent. The right to confidentiality was respected throughout the research: an identification number was assigned to each participant, with the research data being treated anonymously by the researchers.

\section{RESULTS}

Regarding the caregivers' sociodemographic data, their mean age was 50.8 years old (SD \pm 15.4 ), where $82.9 \%$ were female and $68.5 \%$ of the caregivers were married or were living in a stable relationship. It was found that $26.1 \%$ had higher education and that nearly $35.1 \%$ had complete or incomplete compulsory education (up to high school). Regarding their work situation, approximately half of the sample (50.4\%) was not in an active professional situation, being unemployed, retired, disabled (sick pay) or performing house chores, and nearly $40.5 \%$ were employees (with employment). With regard to the degree of kinship, $31.5 \%$ were of a marital nature and $49.5 \%$ of a filial nature. Nearly $22.5 \%$ of the caregivers in the sample had minor children. Regarding religion, it was verified that $83.8 \%$ of the caregivers were Catholics, and nearly $10 \%$ stated not professing any religion. As for the care context, $67.6 \%$ lived with the patient, providing care 7 days a week $(91.9 \%)$, for nearly 12 months (median), with cancer being the most frequent clinical condition (93.7\%).

\section{Presence of the diagnosis}

From the identification of the diagnosis, established by the presence of the three researched criteria simultaneously, the population was divided into those who presented the diagnosis and those who did not.

It was verified that 47 of the 111 caregivers (42.34\%) presented the Nursing diagnosis under study. Caregiver Role Strain was more frequent in older caregivers (mean $=54.5$ years old; SD \pm 13.6 versus mean $=48.2$ years old; $S D \pm 16.2)$, who were spouses $(44.7 \%$ versus $21.9 \%)$ lived with the patient $(56.6 \%$ versus $60.9 \%)$, and with the patient being hospitalized at the time of data collection $(57.4 \%$ versus $42.6 \%)$.

\section{Defining characteristics}

Regarding the frequency of the 29 defining characteristics, in Table 1 it can be seen that "reports difficulty watching care receiver go through the illness" and "Apprehension about the future regarding care receiver's health" were the most frequent in both groups of caregivers, with and without the diagnosis. It is also important to note that all the characteristics (except for the "shame of care recipient") presented higher frequencies in the group of caregivers with strain, indicating that they were associated with the diagnosis under study. In 19 characteristics, the difference between the groups of caregivers with and without the diagnosis was statistically significant (with $p$-values $\leq 0.05$ ).

In the results anchored in Fehring's model, 6 characteristics were classified as major (score $\geq 0.8$ ), 14 as secondary, and the remaining 9 were irrelevant. Of the 14 secondary characteristics, 5 present a score of 0.7 , namely: "fatigue", "stress", "feeling of role captivity", "alteration in sleep pattern" and "financial difficulties". The overall score of the diagnosis was 0.68 . We remind that, if the value is greater than 0.6 , the diagnosis is validated for the population under study ${ }^{13}$. 
Table 1 - Comparison of the frequency of the defining characteristics in caregivers with and without Caregiver Role Strain and Fehring's clinical validation model score. Madeira, Portugal, 2017. ( $n=111)$.

\begin{tabular}{|c|c|c|c|c|c|c|}
\hline \multirow[t]{2}{*}{ Defining characteristic } & \multicolumn{2}{|c|}{$\begin{array}{l}\text { With diagnosis } \\
(n=47)\end{array}$} & \multicolumn{2}{|c|}{$\begin{array}{c}\text { Without diagnosis } \\
(n=64)\end{array}$} & \multirow[t]{2}{*}{$\mathbf{p}^{*}$} & \multirow[t]{2}{*}{$\begin{array}{l}\text { Fehring's } \\
\text { Score }\end{array}$} \\
\hline & $\mathbf{n}$ & $\%$ & $\mathbf{n}$ & $\%$ & & \\
\hline $\begin{array}{l}\text { Lack of time to meet } \\
\text { personal needs }\end{array}$ & 42 & 89.4 & 40 & 62.5 & $0.001^{*}$ & 0.8 \\
\hline $\begin{array}{l}\text { Reports difficulty watching care } \\
\text { receiver go through the illness }\end{array}$ & 43 & 91.5 & 54 & 84.4 & 0.265 & 0.8 \\
\hline $\begin{array}{l}\text { Apprehension about the future } \\
\text { regarding care receiver's health }\end{array}$ & 43 & 91.5 & 53 & 82.8 & 0.186 & 0.8 \\
\hline Preoccupation with care routine & 41 & 87.2 & 45 & 70.3 & $0.035^{\star}$ & 0.8 \\
\hline $\begin{array}{l}\text { Changes in social life and leisure } \\
\text { activities }\end{array}$ & 40 & 85.1 & 39 & 60.9 & $0.005^{\star}$ & 0.8 \\
\hline Emotional lability & 39 & 83.0 & 38 & 59.4 & $0.008^{*}$ & 0.8 \\
\hline Fatigue & 42 & 89.4 & 31 & 48.4 & $\leq 0.001^{*}$ & 0.7 \\
\hline Feeling of role captivity & 38 & 80.9 & 33 & 51.6 & $0.001^{*}$ & 0.7 \\
\hline Stress & 37 & 78.7 & 37 & 42.2 & $\leq 0.001^{*}$ & 0.7 \\
\hline Alteration in sleep pattern & 37 & 78.7 & 38 & 59.4 & $0.031^{*}$ & 0.7 \\
\hline Financial difficulties & 33 & 70.2 & 25 & 39.1 & $0.002^{*}$ & 0.7 \\
\hline Depressive mood & 41 & 87.2 & 28 & 43.8 & $\leq 0.001^{*}$ & 0.6 \\
\hline Ineffective coping & 33 & 70.2 & 14 & 21.9 & $\leq 0.001^{*}$ & 0.6 \\
\hline Impatience & 33 & 70.2 & 26 & 40.6 & $0.002^{*}$ & 0.6 \\
\hline Difficulty performing required tasks & 32 & 68.1 & 29 & 45.3 & $0.017^{*}$ & 0.5 \\
\hline Frustration & 31 & 66.0 & 19 & 29.7 & $\leq 0.001^{*}$ & 0.5 \\
\hline $\begin{array}{l}\text { Apprehensiveness about future } \\
\text { ability to provide care }\end{array}$ & 30 & 63.8 & 33 & 51.6 & 0.197 & 0.5 \\
\hline Somatization & 30 & 63.8 & 33 & 51.6 & 0.197 & 0.5 \\
\hline Worsening of previous diseases & 27 & 57.4 & 13 & 20.3 & $\leq 0.001^{*}$ & 0.5 \\
\hline Anger & 23 & 48.9 & 29 & 45.3 & 0.705 & 0.5 \\
\hline Changes in work/academic activity & 28 & 59.6 & 21 & 32.8 & $0.005^{\star}$ & 0.4 \\
\hline Lack of privacy & 22 & 46.8 & 12 & 18.8 & $0.002^{*}$ & 0.4 \\
\hline Guilt & 19 & 40.4 & 19 & 29.7 & 0.239 & 0.4 \\
\hline Low self-esteem & 17 & 36.2 & 10 & 15.6 & $0.013^{*}$ & 0.3 \\
\hline $\begin{array}{l}\text { Deterioration of family } \\
\text { relationships }\end{array}$ & 17 & 36.2 & 18 & 28.1 & 0.367 & 0.3 \\
\hline $\begin{array}{l}\text { Perception of change in } \\
\text { quality of care provided }\end{array}$ & 19 & 40.4 & 13 & 20.3 & $0.021^{*}$ & 0.2 \\
\hline $\begin{array}{l}\text { Feelings of manipulation } \\
\text { by care receiver }\end{array}$ & 13 & 27.7 & 13 & 20.3 & 0.366 & 0.2 \\
\hline Shame of care receiver & 7 & 14.9 & 11 & 17.2 & 0.746 & 0.1 \\
\hline $\begin{array}{l}\text { Uncertainty and grieving } \\
\text { about changes in relationship } \\
\text { with care receiver }\end{array}$ & 5 & 10.6 & 6 & 9.4 & 0.826 & 0.1 \\
\hline
\end{tabular}

${ }^{*}$ Chi-square test, significance level $\leq 0.05$ 
In addition to the previous analysis, the sensitivity (Se), specificity (Sp), predictive values (PV) and AUC (Area under the ROC Curve) of the defining characteristics of the Caregiver Role Strain Nursing diagnosis were calculated. According to the data in Table 2, two characteristics were present in at least $90 \%$ of the caregivers who presented the diagnosis under study ( $\mathrm{Se}=91.5 \%)$. On the other hand, nine were present in less than half of the caregivers with Caregiver Role Strain $(\mathrm{Se}<50 \%)$.

Regarding specificity, it was verified that 5 characteristics present values above $80 \%$, which indicates that, when these DCs are absent, the caregivers also do not have the diagnosis under study. Still focusing on the analysis of Table 2 , it is verified that the highest positive predictive values are in "ineffective coping" (70.2\%), followed by "worsening of previous diseases" (67.5\%), "lack of privacy" $(64.7 \%)$ and "low self-esteem" (63.0\%). These values indicate the probability of a caregiver with such characteristics having Caregiver Role Strain. With regard to the negative predictive values, it was found that the caregivers who did not present "fatigue" (86.8\%), "Lack of time to meet personal needs" (82.8\%) and "depressive mood" ( $85.7 \%$ ) had a high probability of not suffering Caregiver Role Strain either.

It was verified that, of the nine characteristics classified as irrelevant in Fehring's Model, only "lack of privacy" obtained p-values $\leq 0.05$. For this reason, it is understood that this characteristic has to be considered as secondary rather than as irrelevant.

Table 2 - Sensitivity, specificity and area under the receiver operation curve of the defining characteristics of Caregiver Role Strain. Madeira, Portugal, 2017. ( $n=111)$.

\begin{tabular}{|c|c|c|c|c|c|c|c|}
\hline Fehring & Defining characteristic & $\begin{array}{l}\mathrm{Se}^{\dagger} \\
(\%)\end{array}$ & $\begin{array}{l}\mathrm{Sp}^{\ddagger} \\
(\%)\end{array}$ & $\begin{array}{c}\text { PPV\$ } \\
(\%)\end{array}$ & $\begin{array}{c}\text { NPV\|I } \\
(\%)\end{array}$ & AUC $\pi$ & $\mathbf{P}^{*}$ \\
\hline \multirow{5}{*}{$\frac{. \bar{\sigma}}{\Sigma}$} & $\begin{array}{l}\text { Reports difficulty watching care } \\
\text { receiver go through the illness }\end{array}$ & 91.5 & 15.6 & 44.3 & 71.4 & 0.5 & 0.523 \\
\hline & $\begin{array}{l}\text { Apprehension about the future } \\
\text { regarding care receiver's health }\end{array}$ & 91.5 & 17.2 & 44.8 & 73.3 & 0.5 & 0.436 \\
\hline & Lack of time to meet personal needs & 89.4 & 37.5 & 51.2 & 82.8 & 0.6 & $0.016^{*}$ \\
\hline & Preoccupation with care routine & 87.2 & 29.7 & 47.7 & 76 & 0.6 & 0.129 \\
\hline & $\begin{array}{l}\text { Changes in social life } \\
\text { and leisure activities }\end{array}$ & 85.1 & 39.1 & 50.6 & 78.1 & 0.6 & $0.030^{*}$ \\
\hline \multirow{16}{*}{ 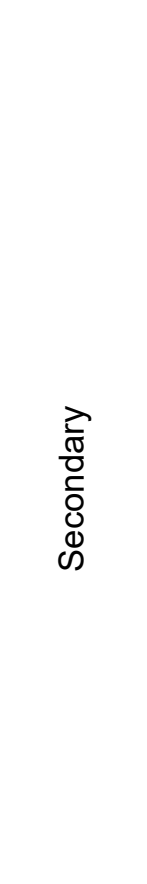 } & Fatigue & 89.4 & 51.6 & 57.5 & 86.8 & 0.7 & $\leq 0.001^{*}$ \\
\hline & Emotional lability & 83.0 & 40.6 & 50.6 & 76.5 & 0.6 & $0.034^{*}$ \\
\hline & Depressive mood & 87.2 & 56.3 & 59.4 & 85.7 & 0.7 & $\leq 0.001^{*}$ \\
\hline & Feeling of role captivity & 80.9 & 48.4 & 53.5 & 77.5 & 0.7 & $0.009^{*}$ \\
\hline & Stress & 78.7 & 57.8 & 57.8 & 78.7 & 0.7 & $0.001^{*}$ \\
\hline & Alteration in sleep pattern & 78.7 & 40.6 & 49.3 & 72.2 & 0.6 & 0.082 \\
\hline & Ineffective coping & 70.2 & 78.1 & 70.2 & 78.1 & 0.7 & $\leq 0.001^{*}$ \\
\hline & Impatience & 70.2 & 59.4 & 55.9 & 73.1 & 0.7 & $0.008^{*}$ \\
\hline & Financial difficulties & 70.2 & 60.9 & 56.9 & 73.6 & 0.7 & $0.005^{*}$ \\
\hline & Difficulty performing required tasks & 68.1 & 54.7 & 52.5 & 70 & 0.6 & $0.041^{*}$ \\
\hline & Frustration & 66.0 & 70.3 & 62.0 & 73.8 & 0.7 & $0.001^{*}$ \\
\hline & $\begin{array}{l}\text { Apprehensiveness about } \\
\text { future ability to provide care }\end{array}$ & 63.8 & 48.4 & 47.6 & 64.6 & 0.6 & 0.271 \\
\hline & Somatization & 63.8 & 48.4 & 47.6 & 64.6 & 0.6 & 0.271 \\
\hline & Changes in work/academic activity & 59.6 & 67.2 & 57.1 & 69.4 & 0.6 & $0.016^{*}$ \\
\hline & Worsening of previous diseases & 57.4 & 79.7 & 67.5 & 71.8 & 0.7 & $0.001^{*}$ \\
\hline & Anger & 48.9 & 54.7 & 44.2 & 59.3 & 0.5 & 0.745 \\
\hline
\end{tabular}


Table 2 - Cont.

\begin{tabular}{|c|c|c|c|c|c|c|c|}
\hline Fehring & Defining characteristic & $\begin{array}{l}\mathrm{Se}^{\dagger} \\
(\%)\end{array}$ & $\begin{array}{l}\mathrm{Sp}^{\ddagger} \\
(\%)\end{array}$ & $\begin{array}{l}\text { PPV\$ } \\
(\%)\end{array}$ & $\begin{array}{l}\text { NPV\| } \\
(\%)\end{array}$ & AUC $\pi$ & $\mathbf{P}^{*}$ \\
\hline \multirow{8}{*}{ 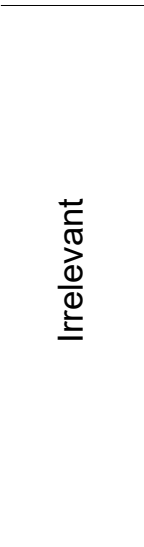 } & Lack of privacy & 46.8 & 81.3 & 64.7 & 67.5 & 0.6 & $0.012^{*}$ \\
\hline & $\begin{array}{l}\text { Perception of change in } \\
\text { quality of care provided }\end{array}$ & 40.4 & 79.7 & 59.4 & 64.6 & 0.6 & 0.071 \\
\hline & Guilt & 40.4 & 70.3 & 50 & 61.6 & 0.6 & 0.335 \\
\hline & Low self-esteem & 36.2 & 84.4 & 63 & 64.3 & 0.6 & 0.065 \\
\hline & Deterioration of family relationships & 36.2 & 71.9 & 48.6 & 60.5 & 0.5 & 0.470 \\
\hline & $\begin{array}{l}\text { Feelings of manipulation } \\
\text { by care receiver }\end{array}$ & 27.7 & 79.7 & 50.0 & 60.0 & 0.5 & 0.510 \\
\hline & Shame of care receiver & 14.9 & 82.8 & 38.9 & 57.0 & 0.5 & 0.837 \\
\hline & $\begin{array}{l}\text { Uncertainty and grieving about changes } \\
\text { in relationship with care receiver }\end{array}$ & 10.6 & 90.6 & 45.5 & 58.0 & 0.5 & 0.910 \\
\hline
\end{tabular}

${ }^{*}$ Chi-square test significance level $\leq 0.05, \dagger$ Sensitivity, $\ddagger$ Specificity, §Positive Predictive Value, ||Negative Predictive Value, TArea under the ROC curve

Chart 1 reflects the articulation of the methods used to define the best indicators of the Caregiver Role Strain Nursing diagnosis in palliative care. It was verified that, of the 29 characteristics tested in the clinical validation, 9 were classified as major, 13 as secondary and 7 as irrelevant.

Chart 1 - Proposal of the defining characteristics of the Caregiver Role Strain Nursing diagnosis. Madeira, Portugal, 2017.

\begin{tabular}{|c|c|c|}
\hline Major & Secondary & Irrelevant \\
\hline $\begin{array}{l}\text { Apprehension about the future } \\
\text { regarding care receiver's health } \\
\text { Preoccupation with care routine } \\
\text { Lack of time to meet } \\
\text { personal needs } \\
\text { Emotional lability } \\
\text { Depressive mood } \\
\text { Fatigue } \\
\text { Changes in social life } \\
\text { and leisure activities } \\
\text { Reports difficulty watching } \\
\text { care receiver go through } \\
\text { the illness } \\
\text { Feeling of role captivity }\end{array}$ & $\begin{array}{c}\text { Apprehensiveness about } \\
\text { future ability to provide care } \\
\text { Difficulty performing } \\
\text { required tasks } \\
\text { Stress } \\
\text { Ineffective coping } \\
\text { Frustration } \\
\text { Impatience } \\
\text { Alteration in sleep pattern } \\
\text { Anger } \\
\text { Somatization } \\
\text { Worsening of previous diseases } \\
\text { Changes in work/academic activity } \\
\text { Lack of privacy } \\
\text { Financial difficulties }\end{array}$ & $\begin{array}{c}\text { Perception of change in } \\
\text { quality of care provided } \\
\text { Guilt } \\
\text { Low self-esteem } \\
\text { Uncertainty and grieving } \\
\text { about changes in relationship } \\
\text { with care receiver } \\
\text { Deterioration of family } \\
\text { relationships } \\
\text { Feelings of manipulation } \\
\text { by care receiver } \\
\text { Shame of care receiver }\end{array}$ \\
\hline
\end{tabular}

\section{DISCUSSION}

Caregiver Role Strain is a phenomenon present in the context of palliative care;,79-10,24 however, this diagnosis had not yet been validated in this population. Its prevalence has been high among caregivers of people in different situations. A validation study conducted with caregivers of people after stroke in Brazil revealed a prevalence value of $73.8 \%{ }^{25}$, and another study with caregivers of 
dependent people, carried out in the Czech Republic, revealed a prevalence of $82.2 \%{ }^{26}$. Such results are far above those found in this sample (42.3\%), and this fact may be related to several factors. One of them can be the fact that the criteria for establishing the diagnosis are so different in different studies, which could lead to divergent results. On the other hand, the sample of caregivers in this study was monitored by a team specialized in palliative care, whose intervention is believed to exert an impact on reducing the strain levels, as support to the family is one of the pillars of palliative care.

The identification of the profile of the caregiver with role strain - spouse, with a mean age of 54.5 years old, who lives with the patient and has the patient hospitalized - will contribute to a more targeted Nursing intervention and highlights the fact that, even when the patient is hospitalized in a palliative care service, Caregiver Role Strain remains.

With regard to the defining characteristics, of the 29 tested, seven were considered irrelevant. Almost all nine DCs classified as major in this study were already included in the NANDA-I classification (with the exception of the "feeling of role captivity", which emerged from the integrative literature review). These characteristics constitute the most frequent set of clinical indicators, they indicate the presence of the Caregiver Role Strain diagnosis, and have also been found in previous validation studies of this diagnosis ${ }^{25-27}$.

It is noteworthy that "apprehension about the future regarding care receiver's health" and "reports difficulty watching care receiver go through the illness", classified as major, are very sensitive $(91.5 \%)$, although not very specific (17.2\%:15.6\%), reflected in the AUC with values of 0.5 , without statistical significance. Despite this performance in the diagnostic accuracy measures, these DCs proved to be crucial for the diagnosis, as they were the ones that appeared more frequently in the caregivers (91.5\%). Making an analogy with the "pain" symptom, this is also a very sensitive symptom in several diagnoses, although not very specific, needing other attributes for greater diagnostic accuracy.

One of the criticisms to Fehring's model refers precisely to the results found in the aforementioned example, in which the score obtained ( 0.8 in both) is highly influenced by the prevalence of the DC in the sample under study, devaluing the relationship between the individuals who have the diagnosis and those who do not ${ }^{17}$. The association of other accuracy measures, such as those used in this study, may help in the decision to maintain or exclude the DC.

The "feeling of role captivity" is a new DC, which emerged in $80.9 \%$ of the caregivers with strain and in $51.6 \%$ of those without strain ( $p=0.001$ and significant value in the AUC $[p=0.009]$ ). This feeling of caregiver role captivity, of wanting to flee and distance from everything, constitutes a way of emotionally dealing with all those experiences that are lived. This sensation of ties, of deprivation of freedom, does not imply that the caregiver literally wants to abandon the care of their sick family member. The desire to flee is often associated with feelings of guilt, as these thoughts can become intrusive and little promoters of the caregiver's emotional well-being. This clinical indicator has emerged in studies conducted with caregivers of people with dementia ${ }^{3}$, and has not been identified in the context of palliative care, which suggests that the findings of this research are innovative.

Another DC considered as major was "Fatigue", present in $89.4 \%$ of the caregivers with role strain, with a statistically very significant difference $(p<0.001)$ in relation to the group without the diagnosis. It also obtained a high NPV (86.8\%), implying that a large percentage of caregivers without "fatigue" also had no strain, which may be considered a good predictor of the diagnosis. A research study carried out in caregivers of people in palliative care situations in the Netherlands concluded that high levels of fatigue were related to high strain levels ${ }^{8}$. In other validation studies, this DC was classified as secondary ${ }^{26}$. 
Of the 13 characteristics classified as secondary in our study, 3 are not included in NANDA-I. "Worsening of previous diseases" was found in $57.4 \%$ of the caregivers with strain, as opposed to $20.3 \%$ in caregivers without the diagnosis, this difference being statistically very significant $(p \leq 0.001)$. The results obtained in the analysis of the accuracy measures confirm that this could be a good indicator of the presence of the diagnosis.

The physical and emotional effort required to take care of a family member activates neurochemical, endocrine and metabolic processes, which can lead to organic and emotional changes that are detrimental to the caregiver's health ${ }^{28}$. The association between the worsening of some physical diseases and Caregiver Role Strain was described in previous research studies ${ }^{28-29}$.

"Ineffective coping" was a DC that was already in the taxonomy, and was maintained after the review. In this study, it was present in $70.2 \%$ of the caregivers with strain, and only in $21.9 \%$ of the caregivers without the diagnosis $(p \leq 0.001)$, proving to be quite discriminatory of caregiver strain. Ineffective coping strategies was the DC that obtained the best result in the AUC, 0.7 with p-value $\leq 0.001$, expressing the best articulation between the sensitivity and specificity values. It was found among the most specific DCs with $78.1 \%$ and also very satisfactory predictive values, in which $70.2 \%$ of the caregivers with ineffective coping presented strain and $78.1 \%$ of the caregivers without ineffective coping did not present the diagnosis. Caring for a family member at the end of life is fraught with challenges, sometimes affecting the ability to adapt and solve problems. This fact makes the caregiver feel incapable or powerless to find adaptive solutions to the most varied challenges that arise during this process.

Several studies have investigated the coping mechanisms used by caregivers of people in palliative care situations. A research study conducted in the USA verified that escape-avoidance was the most frequently used coping mechanism to mediate the relationship between strain and psychological symptoms of the patients ${ }^{23}$. In another study, it was found that, when female caregivers used coping mechanisms focused on emotion, this was associated with greater strain ${ }^{30}$.

Seven DCs were excluded, equally excluded in other validation studies; for example, "deterioration of family relationships" 25 and "Uncertainty/Grieving about change in relationship with care receiver" 25 .

Some characteristics that are not included in NANDA-I, and that emerged from the integrative review, were classified as irrelevant in the clinical validation in caregivers of people in palliative care situations. It is then implied that these characteristics may be found in other populations of caregivers of people with different health problems; for example, the "feelings of manipulation" that arise in caregivers of people with Parkinson's disease and dementia, or the "shame of the family member" that occurs in caregivers of people with mental illness ${ }^{5}$, or in people post-stroke ${ }^{25}$.

These results reinforce that the care for a sick or dependent family member varies according to the caregivers' characteristics, but also to the clinical context of care, since, in relation to some DCs associated with Caregiver Role Strain in other populations, no significant associations were found in this context of palliative care.

Throughout this study, it was a concern ensuring scientific rigor; however, some limitations may still persist, deserving due consideration. One of them is related to the type and size of the sample, which is not randomized, with the possibility that the number of caregivers was higher. In the sense of improvement, a replica of this study is proposed, with a randomized probabilistic sample and application in a palliative care unit. The fact that it was always the same researchers who carried out the entire data collection proved to be a strength of the study, as the criteria to identify who presented, or did not present, the diagnosis were not influenced by who the evaluator was, as is the case with other research studies in which several nurses/researchers do so. 


\section{CONCLUSION}

Through this study, it was possible to clinically validate the Caregiver Role Strain Nursing diagnosis for a population of caregivers of people in palliative care situations. Based on three criteria, a $42.3 \%$ prevalence of the diagnosis was established. The use of several methods in the validation contributed to greater robustness of the results obtained, which could be replicated in future research studies and in different care contexts. Of the 29 defining characteristics subjected to clinical validation, 22 were considered valid (major or secondary) and seven, irrelevant. Four of the characteristics tested were not part of NANDA-I. Therefore, it is concluded that the diagnosis needs to be revised in taxonomy.

\section{REFERENCES}

1. Bauer J, Sousa-Poza A. Impacts of Informal Caregiving on Caregiver Employment, Health, and Family. J Popul Ageing [Internet]. 2015 [cited 2020 Sep 3];8:113-45. Available from: https://doi. org/10.1007/s12062-015-9116-0

2. Vechia ADRD, Mamani ARN, Azevedo RCS, Reiners AAO, Pauletto TT, Segri NJ. Caregiver Role Strain In Informal Caregivers for the Elderly. Texto Contexto Enferm [Internet]. 2019 [cited 2020 Sep 3];28:e20180197. Available from: https://doi.org/10.1590/1980-265X-TCE-2018-0197

3. Liu Y, Dokos M, Fauth EB, Lee YG, Zarit SH. Financial Strain, Employment, and Role Captivity and Overload Over Time Among Dementia Family Caregivers. Gerontologist [Internet]. 2019 [cited 2020 Sep 3];59(5):e512-e520. Available from: https://doi.org/10.1093/geront/gnz099

4. Dias ES, Moura HFS, Tannus CDA, Pacheco MP, Lemos GVL, Ribeiro LRT, et al. Conflitos emocionais em cuidadores de pacientes com doença de alzheimer. Braz J Dev [Internet]. 2020 [cited 2020 Sep 3];6(5):29036-50. Available from: https://www.brazilianjournals.com/index.php/ brjd/article/view/10285/9477

5. Silva N, Sardinha L, Lemos V. The impact of alzheimer's disease on the caregiver's mental health. Diálogos Interdisciplinares [Internet]. 2020 [cited 2020 Sep 3];9(4):48-57. Available from: https://revistas.brazcubas.br/index.php/dialogos/article/view/935

6. Costa TFD, Pimenta CJL, Nobrega M, Fernandes M, Franca ISX, Pontes MLF, et al. Burden on caregivers of patients with sequelae of cerebrovascular accident. Rev Bras Enferm [Internet]. 2020 [cited 2020 Sep 3];73(6):e20180868. Available from: https://doi.org/10.1590/0034-71672018-0868

7. Spatuzzi R, Giulietti MV, Ricciuti M, Merico F, Fabbietti P, Raucci L, et al. Exploring the associations between spiritual well-being, burden, and quality of life in family caregivers of cancer patients. Palliat Support Care [Internet]. 2018 [cited 2020 Sep 3];17(3):294-9. Available from https://doi. org/10.1017/s1478951518000160

8. Peters M, Goedendorp MM, Verhagen S, Smilde TJ, Bleijenberg G, van der Graaf WTA. A prospective analysis on fatigue and experienced burden in informal caregivers of cancer patients during cancer treatment in the palliative phase. Acta Oncol [Internet]. 2015 [cited 2020 Sep 3];54(4):500-6. Available from https://doi.org/10.3109/0284186x.2014.953254

9. Guerriere D, Husain A, Zagorski B, Marshall D, Seow H, Brazil K, et al. Predictors of caregiver burden across the home-based palliative care trajectory in Ontario, Canada. Health Soc Care Community [Internet]. 2016 [cited 2020 Sep 3];24(4):428-38. Available from: https://doi.org/10.1111/ hsc. 12219

10. Seibl-Leven M, von Reeken C, Goldbrunner R, Grau S, Ruge MI, Galldiks N, et al. Clinical routine assessment of palliative care symptoms and concerns and caregiver burden in glioblastoma patients: an explorative field study. J Neuro-oncol [Internet]. 2018 [cited 2020 Sep 3];138(2):32133. Available from: https://doi.org/10.1007/s11060-017-2487-8 
11. Herdman T, Kamitsuro S. Diagnóstico de Enfermagem da NANDA-I: Definições e classificação 2018-20. 11th ed. Porto Alegre, RS(BR): Artmed; 2018.

12. Lourenço TMG, Abreu-Figueiredo RMS, Sá LO. Review of nursing diagnosis validation studies: caregiver role strain. Rev Gaúcha Enferm [Internet]. 2020 [cited 2020 Sep 30];41:e20190370. Available from: https://doi.org/10.1590/1983-1447.2020.20190370

13. Fehring RJ. Methods to validate nursing diagnoses. Heart Lung [Internet]. 1987 [cited 2020 Sep 3];16(6):1-9. Available from: https://epublications.marquette.edu/nursing_fac/27/

14. Fehring RJ. The Fehring Model. In: Carroll-Johnson RM, Paquette M, eds. Classification of Nursing Diagnoses: Proceedings of the Tenth Conference. North American Nursing Diagnosis Association. Philadelphia: Lippincott; 1994. p. 55-62.

15. Silva RA, Melo GAA, Caetano JÁ, Lopes M, Butcher HK, Silva VMd. Accuracy of nursing diagnosis "readiness for enhanced hope" in patients with chronic kidney disease. Rev Gaúcha Enferm [Internet]. 2017 [cited 2020 Sep 10];38(2):e65768. Available from: https://doi.org/10.1590/19831447.2017.02.65768

16. Borges LSR. Diagnostic Accuracy Measures in Cardiovascular Research. Int J Cardiovasc Sci [Internet]. 2016 [cited 2020 Sep 10];29(3):218-22. Available from: https://doi.org/10.5935/23594802.20160030

17. Lopes M, Silva V, Araujo T. Methods for Establishing the Accuracy of Clinical Indicators in Predicting Nursing Diagnoses. Int J Nurs Knowl [Internet]. 2012 [cited 2020 Sep 10];23(3):13439. Available from: https://doi.org/10.1111/j.2047-3095.2012.01213.x

18. Carteiro D, Caldeira S, Sousa L, Costa D, Mendes $C$. Clinical validation of the nursing diagnosis of sexual dysfunction in pregnant women. Int J Nurs Knowl [Internet]. 2016 [cited 2020 Sep 10];28(4):219-24. Available from: https://doi.org/10.1111/2047-3095.12139

19. Caldeira S, Timmins F, Carvalho EC, Vieira M. Clinical Validation of the Nursing Diagnosis Spiritual Distress in Cancer Patients Undergoing Chemotherapy. Int J Nurs Knowl [Internet]. 2017 [cited 2020 Sep 10];28(1):44-52. Available from: https://doi.org/10.1111/2047-3095.12105

20. Abreu-Figueiredo R, Sá LO, Lourenço TM, Almeida SS. Death anxiety in palliative care: Validation of the nursing diagnosis. Acta Paul Enferm [Internet]. 2019 [cited 2020 Sep 10];32(2):178-85. Available from: https://doi.org/10.1590/1982-0194201900025

21. Zarit SH. ZBI-Zarit Burden Interview Version 1.0: Scaling and Scoring. 6th ed. Lyon: Mapi Research Trust; 2018.

22. Gonçalves-Pereira M, Zarit SH. The Zarit Burden Interview in Portugal: Validity and Recommendations in Dementia and Palliative Care. Acta Med Port [Internet]. 2014 [cited 2020 Sep 10];27(2):163-5. Available from: https://doi.org/10.20344/amp.5107

23. Lopes MVdO, Silva VMd, Araujo TLd. Validation of nursing diagnosis: challenges and alternatives. Rev Bras Enferm [Internet]. 2013 [cited 2020 Sep 10];66(5):649-55. Available from: https://doi. org/10.1590/S0034-71672013000500002

24. Washington KT, Wilkes CM, Rakes CR, Otten SJ, Oliver DP, Demiris G. Relationships among symptom management burden, coping responses, and caregiver psychological distress at end of life. J Palliat Med [Internet]. 2018 [cited 2020 Sep 10];21(9):1234-41. Available from: https:// doi.org/10.1089/jpm.2017.0584

25. Oliveira AR, Cordeiro R, Carvalho V, Costa A, Lopes M, Araujo T. Clinical indicators of 'caregiver role strain' in caregivers of stroke patients. Contemp Nurse [Internet]. 2013 [cited 2020 Sep 18];44(2):215-24 Available from: https://doi.org/10.5172/conu.2013.44.2.215 
26. Zeleníková R, Kozáková R, Jarošová $D$. Clinical Validation of the Nursing Diagnosis Caregiver Role Strain in the Czech Republic. Int J Nurs Knowl [Internet]. 2014 [cited 2020 Sep 18];25(2):804. Available from: https://doi.org/10.1111/2047-3095.12020

27. Silva KJ, Dias JL, Silva Neto MG, Araújo HSO, Bastos AM, Martins MA, Montefusco SRA, Pereira AL. Nursing diagnosis tension of the role of caregiver in family members of people with chronic wounds. DRIUFT [Internet]. 2020 [cited 2020 Sep 30];7(3):97-105. Available from: https://doi. org/10.20873/uftv7-7815

28. Romero-Martinez A, Hidalgo-Moreno G, Moya-Albiol L. Neuropsychological consequences of chronic stress: the case of informal caregivers. Aging Ment Health [Internet]. 2018 [cited 2020 Sep 30];24(2):259-71. Available from: https://doi.org/10.1080/13607863.2018.1537360

29. Sousa JIS, Silva BT, Rosa BM, Garcia EQM, Roque TS. Work overload in elderly relatives in palliative care. Res Soc Dev [Internet]. 2020 [cited 2020 Sep 30];9(4):e146943001. Available from: https://doi.org/10.33448/rsd-v9i4.3001

30. Schrank B, Ebert-Vogel A, Amering M, Masel EK, Neubauer M, Watzke H, et al. Gender differences in caregiver burden and its determinants in family members of terminally ill cancer patients. Psycho-Oncology [Internet]. 2016 [cited 2020 Sep 30];25(7):808-14 Available from: https://doi. org/10.1002/pon.4005 


\section{NOTES}

\section{ORIGIN OF THE ARTICLE}

Extracted from the thesis - Clinical Validation of the Caregiver Role Strain Nursing Diagnosis in Family Caregivers of Patients in Palliative Care, presented to the PhD Program in Nursing of Universidade Católica Portuguesa, in 2019

\section{CONTRIBUTION OF AUTHORITY}

Study design: Lourenço TM, Sá LO.

Data collection: Lourenço TM, Abreu-Figueiredo RM.

Data analysis and interpretation: Lourenço TM, Abreu-Figueiredo RM, Sá LO.

Discussion of the results: Lourenço TM, Abreu-Figueiredo RM.

Writing and/or critical review of the content: Lourenço TM, Abreu-Figueiredo RM, Sá LO.

Review and final approval of the final version: Lourenço TM, Sá LO.

\section{ACKNOWLEDGMENT}

Funding: The authors thank the Portuguese Foundation for Science and Technology (FCT/MCTES) for the financial support of the Center for Interdisciplinary Research in Health (UIDB/04279/2020) of Universidade Católica Portuguesa.

\section{APPROVAL OF ETHICS COMMITTEE IN RESEARCH}

Approved by the Research Ethics Committee of the Regional Health Service of the Autonomous Region of Madeira, Public Business Entity, opinion No. 44/2014.

\section{CONFLICT OF INTEREST}

There is no conflict of interest.

\section{EDITORS}

Associated Editors: Selma Regina de Andrade, Gisele Cristina Manfrini, Elisiane Lorenzini, Monica Motta Lino.

Editor-in-chief: Roberta Costa.

\section{HISTORICAL}

Received: November 16, 2020.

Approved: June 15, 2021.

\section{CORRESPONDING AUTHOR}

Tânia Marlene Gonçalves Lourenço

tmlourenco@esesjcluny.pt 